\title{
POSTPRINT
}

\section{Perspectivity and professional role in verbal interaction ${ }^{\star}$}

\author{
Inken Keim \\ Institute for the German Language, Mannheim
}

The main point of this chapter is to demonstrate how a speaker's concept of his/her professional role can be inferred from his/her perspectival work (perspective setting and relating different perspectives to one another) in professional encounters. Thereby some risks of complex perspectival work in discourse will become manifest which result - at one point in the talk - in perspectival inconsistency, revealing a deeply grounded social problem for the speaker. This will be examined in the framework of a rhetorical conversation analysis. ${ }^{1}$

The aims of the analysis are:

- to reconstruct the speaker's concept of her professional role from her perspectival work;

- to illustrate the complexity of her perspectival work on the one hand, and its risks on the other, as they can be seen in perspectival break and inconsistency; and

- to present some interactional and contextual conditions for this perspectival break.

After a short description of the theoretical and methodological framework (1), and a short outline of the empirical data (2), in the main part of this chapter these phenomena of perspectivation will be illustrated through the analysis of an ethnographic interview with a professional social worker, and the analytical aims, presented above, will be discussed within the framework of a rhetorically oriented conversation analysis (3). 


\section{The concept of perspectivation in discourse}

The idea of perspectivity, developed from the presentational technique in Renaissance art, was adopted by Leibniz as a central part of a theory of cognition, ${ }^{2}$ and is now used as a central concept in various scientific fields, in arts, literature, linguistics, social psychology, and sociology. The concept includes the idea that all human perception depends upon the temporal, spatial and cognitive standpoint of the spectator/observer. The relation between the perceived object and the observer's/perceiver's local and/or cognitve standpoint is a constitutive element of the object's construction. The viewpoint from which the object is perceived is never visible in the object's presentation, but can be reconstructed from that presentation.

Perspectivity is incorporated in a language's grammar and lexicon. ${ }^{3}$ In linguistics, perspectivity is, on the one hand, included in deictic concepts; ${ }^{4}$ on the other hand, it is an independent concept as e.g. in Fillmores' case theory (1972/1977). There, the concept of perspectivity is related to cognitive scenes. In verbalizing these scenes, a speaker must select some elements of the scene to be represented in the verbal surface, and he has to decide which of these elements should appear as the subject or direct object of a sentence. The verbalized elements of the scene are brought "into the foreground" or "into perspective" $(1977: 17,18)$, while other elements are only cognitively present, and not verbalized, and therefore "out of perspective". ${ }^{5}$ In later linguistic work, the term perspectivity is related more to grammatical phenomena, to grammatical and lexical conversions, ${ }^{6}$ to lexical derivational processes in combination with different agents. ${ }^{7}$

These concepts of perspectivity are based upon cognitive scenes and the grammatical structure of sentences. They are not sufficient for the analysis of perspectivation in interaction. Here, perspectivity becomes relevant as a global structure, and consistency of action is essentially established by consistentcy of perspectivation over long discourse sections. The starting point for our concept of perspectivation in discourse is Graumann's (1993) phenomenologically oriented idea of perspectivity. According to Graumann, "perspectivity" is a cognitive concept which denotes the interrelation and mutual definition of the elements "viewpoint" (= the position of the observer), "aspect" (= what can be seen of an object from a given viewpoint), and "horizon" (= the whole context of reference for the experience of that object). The perception of certain aspects of an object (in relation to one's position) is always combined with the anticipation of further aspects of this object in relation to its horizon. Perspectivity has a dynamic quality that is characterized by a permanent transition from experience to the potentiality of further experience. Setting or adopting a perspective means structuring and framing the perceived object in relation to a given viewpoint. Therefore, the perception and categorization 
of objects as much as the solution of problems differ in relation to the perceiver's or actor's point of view.

The concept of perspectivation that I use for the analysis of perspectivation in discourse is a further elaboration of Graumann's concept. It was developed in the context of an approach of a conversational rhetoric. ${ }^{8}$ In addition to concepts of perspectivity drawn from visual or cognitive perception ${ }^{9}$ our concept of perspectivation in discourse is modelled along the following lines: in verbal interaction, participants' perspectives as much as their standpoints are part of the social situation, and they are explicitly or implicitly presented in participants' perspectival work. Participants' standpoints are especially defined by their membership of social categories, as they result from a mutual attribution and negotiation in interaction. There exists a strong link between a participant's perspective and the social type or category to which this participant "belongs". Perspectives attributed to social types are typified too, which means that there exist culture-specific, typified perspectives of social categories like "doctor", "priest", "mother", "adviser", etc. In discourse, participants have to take into account these typified perspectives; they function as a constraint as well as a resource for the elaboration of an individual perspective; and a very private perspective can be hidden behind a typified one.

Verbal interaction is structured as a process of perspective setting and perspective taking (see Graumann 1989). Perspective setting means that in order to make one's actions comprehensible and to enable others to deal with one's perspective, a speaker has to reveal his/her perspective up to a certain extent and with some consistency. A certain perspective, once established, affects the ongoing process of the construction of meaning. When others' perspectives are presented, this change of perspective has to be marked, and the speaker's own perspective presented up till now has to be related to them. Perspective taking means that recipients have to show how they interpret the manifested perspective, and how they relate their own perspective to it. Both parts of perspective work constitute a process of negotiating common ground (or excluding it).

In verbal interaction participants not only model discourse objects according to their perspectives, but they define the whole social situation and the ongoing interaction process in relation to their perspectives. Participants' perspective divergences (in relation to these interactive tasks) have to be dealt with, and the negotiated common ground of "what is relevant and what has to be dealt with in what fashion" - that is the selection of interaction schemata and interaction modalities manifests the current construction of social meaning as well as forming the frame for further interaction.

In most cases, a specific perspective is not directly visible or explicitly expressed in a single utterance, but has to be reconstructed. The relation between an overarching perspective and a locally produced verbal activity is established by contextualization. ${ }^{10}$ In Gumperz' concept of contextualization, context is not only concep- 
tualized as the material or social environment in which the discourse takes place, but as an interactively produced construction. This means that interlocutors use contextualization devices in the process of their verbal activities, thereby building the contexts necessary for an adequate interpretation of their utterances. Such contexts consist of schematic knowledge; they are the frames for the construction of meaning. In other words, context is not an external element of an interaction (e.g. the speakers' membership of social categories) which automatically determines the course of an interaction. A contextual phenomenon becomes interactionally relevant when interactants make it part of their interaction. And this is typically signalled via contextualization devices: interactants make clear how - in the ongoing interaction - their actions and relations are to be interpreted.

One possibility of referring to a social type or category to which a typical perspective is attributed, is by social symbolization; ${ }^{11}$ this means that the way in which a person's acting, thinking, evaluating, etc. is presented, points to the social category/type in which this person is placed by the speaker. The main devices for social symbolization are quotations with code-switching and formulaic utterances indicating the way the person presented typically speaks, and pragmatic rules the presented person typically follows in the presented social situation.

Contextualization is most effective when it is performed on all linguistic levels at the same time: prosody, lexico-semantics, syntax and pragmatics. In order to indicate the social type or category to which a presented perspective is allocated, all cues have to point "in the same direction". This means that only those features are choosen which are relevant for the implied social type/category. What is relevant in relation to a social unit is provided by general background knowledge that is shared by participants of the same social world or culture. The analyst, on the other hand, must reconstruct this background knowledge; it can be attained by ethnographic research. ${ }^{12}$

\section{The data}

The empirical data for the following analysis is an ethnographic interview with the main social worker of a West German organization, called "Bund der Mitteldeutschen". The organization was founded and is run by Germans who, after World War II and during the Cold War came from Eastern parts to West-Germany. As long as the GDR existed, the main task of the organization was to help citicens of the GDR who wanted to leave their country, and to help them integrate into Western life. After German reunification in 1990, the organization lost its main purpose and had to redefine its goals. The new task was defined as mediating between antagonistic social groups whose problems became important in the 
course of German reunification: the antagonistic attitudes between "Ossis" (East Germans) and "Wessis" (West Germans) on the one hand, especially in Berlin, and between "Ossis" and "Übersiedler" (GDR-exiles) on the other. The problem of the relationship between Ossis and GDR-exiles is a special one: both groups consist of members who came from the GDR; Ossis lived in the GDR until reunification, while the "Übersiedler" left the GDR, often under dramatic circumstances, when it was still a separate state. At that time, both groups saw the other according to negative stereotypes: From the Ossi's perspective, ${ }^{13}$ the GDR-exile is seen as a "Vaterlandsverräter" (traitor of his home-country) $;^{14}$ from the GDR-exile's perspective, the Ossi is "a coward, an opportunist, a conformist careerist, and he has betrayed the people who wanted to leave the GDR".

The ethnographic interview I present here, took place in June 1991, six months after German reunification. My informant, BE, the social worker with the BMD, is herself a GDR-exile. She was a political opponent in the GDR, and before she was allowed to leave, she was harassed, isolated and persecuted. She came to West Germany in 1988, and she had a very difficult start in the West. After a long period of unemployment, she finally found a job as a social worker with the BMD.

At work BE must deal with the structural problem of her professional role as mediator between the antagonistic groups Ossis and GDR-exiles. On the one hand, her membership of one of the social categories is a condition and resource for doing the job: she has a deep insight into and understanding of her Eastern clientele's problems. She knows the typical (and stereotypical) Ossis' perspective on Western life, and she knows the typical (and stereotypical) Western perspective towards Easterners, at least as it is expressed in the context of her organization. On the other hand, her negative experiences during the last few years of her life in the GDR influence her attitude towards Easterners and are likely to interfere with her task as mediator.

\section{Analysis}

The main part of the interview is BE's self-presentation in her professional role as mediator between the antagonistic pairs of groups, Ossis-Wessis on the one hand, and Ossis-GDR-exiles on the other. BE illustrates some problems of her profession by describing an exemplary conflict scenario, in which members of these groups confront one another, and she acts as mediator. The illustration of this situation imposes great demands on the presentation and distinction of different and antagonistic perspectives on various topics, of their interrelation and their respective evaluation. BE's perspectival work reflects her definition of the role of mediator.

In these parts of the interview, the main rhetorical tasks BE must cope with are: 
- contextualizing the various perspectives, i.e. giving cues that a specific perspective on a given subject matter is presented, and symbolizing and evaluating the social category (Easterner, Westerner, GDR-exile) to which this perspective is attributed,

- constructing relations between different perspectives that are consistent with the definition of her professional role as mediator, and

- managing her negative attitudes towards one of the groups, the Ossis.

3.1 Reconstructing the speaker's professional role from her perspectival work

The following transcript segment is a good example of the complexity of BE's perspectival work. Preceding this segment, BE outlines her professional task: to organize work-meetings between the antagonistic groups, to initiate discussions, to try to reduce stereotypes and prejudices on both sides; to motivate both sides to speak with each other, a task that - according to $\mathrm{BE}$ - is very hard to accomplish. When $\mathrm{BE}$ gives reasons for this statement, she presents herself as an expert on the Eastern perspective on German reunification:

$425 \mathrm{BE}: \quad \rightarrow$ wi" $r d$ sich nich ändern $\leftarrow \downarrow$ that won't change

$426 \mathrm{~K}$

427 IN:

un warum meinen sie $\uparrow$

$\# \leftarrow$ weil der because \#FALTERING and why do you think so

$428 \mathrm{BE}:$ hass- * in den- * äh neuen fünf bundesländern gegen äh- * the hate in the five new states against the old German

$429 \mathrm{BE}: \quad$ die- * a"ltbundesrepublikfederal republic

$430 \mathrm{IN}$ :

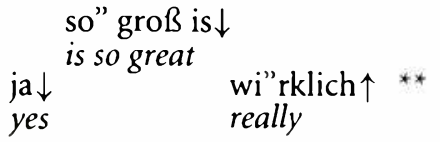

$431 \mathrm{BE}: \quad$ wir werden da- ${ }^{*}$ denk ich- * noch ga"nz schön- * schwierigwe will get I think lots of difficulties

$432 \mathrm{BE}: \quad$ keiten-* ham $\downarrow \#$

$433 \mathrm{~K}$

434 IN:

\#

ham sie des jetzt erfahrn auf ihren reisen oder did you learn that on your trips or

435 BE: $\quad$ ja $\downarrow \quad$ de $=$ s mei"n eindruck $\downarrow$ yes this is my impression

$436 \mathrm{IN}:$ is des äh so allgemeine- * ähis this a general 
$437 \mathrm{BE}: \quad$ mei" $n$ eindruck un- ${ }^{*} \rightarrow$ muß eintlich sa:ng- ${ }^{*}$ toitoitoi

438 IN: ja $\downarrow^{m y}$

$$
\text { my impression and Ihave to say knock on wood }
$$

$439 \mathrm{BE}$ : darauf konnt ick mich \#immer verlassen $\leftarrow \#{ }^{*}>$ so- * prognosen

$440 \mathrm{~K}$ that I could always depend on this

\#LAUGHING \#

making a prognosis

44l BE: zu stellen in dem rahmen ja $\uparrow$ * von anfang an äh wo die in this context right from the beginning

$442 \mathrm{BE}:$ mauer jefallen is: hab ick- * also- * äh- * jesagt \#also so"

$443 \mathrm{~K}$ when the wall came down I said well it

444 BE: einfach jeht det nich $\downarrow<\#$ ik saje \# -ih"r könnt det schon ga" $r$

$445 \mathrm{~K}$ FULLY \# \#XPRESSIVELY

446 BE: nich- * mit dem- * äh o"stbürger so" machen- * wie ih"r euch the way you want especially not Easterners

$447 \mathrm{BE}: \quad$ det vorstellt $\downarrow \rightarrow \# \quad \rightarrow$ ik meine die ham oo"ch ne vor$448 \mathrm{~K}$

449 IN: I mean they have their ideas

$450 \mathrm{BE}: \quad$ stellung $\downarrow \leftarrow \leftarrow^{*}$ bloß- * \#die" stehn ja in einer erwartungs-

$451 \mathrm{~K}$

$$
\text { \# } \mathrm{mhm} \downarrow
$$

$452 \mathrm{BE}$ : haltung- * die äh- * die ihr überhaupt nich abdecken which you can never satisfy

453 BE: könnt $\downarrow$ \# beziehungsweise wo i:h"r dann sagt - * \#na ihr that is when you say then hey

$454 \mathrm{~K}$

$455 \mathrm{IN}$ :

\#

\#DEROGA-

$\mathrm{mhm} \downarrow$

$456 \mathrm{BE}: \quad$ müß t doch wohl tullern ja $\uparrow \# \quad$ ihr werft uns vor- * wir you must be mad

$457 \mathrm{~K}$ TORILY

you accuse us we

$458 \mathrm{IN}$ :

\#

$\mathrm{mhm} \downarrow$ *

459 BE: mußten vierzig jahre lang krieg weiter spieln un nun könnt had to go on playing war for forty years and now you 
$460 \mathrm{BE}: \quad$ ihr zahln- $\quad$ is ja ooch total äh stussig ja $\uparrow$

461 IN: can pay $\mathrm{mhm} \downarrow$ that is totally absurd $\mathrm{mhm} \downarrow$ what the

462 BE: ostbürjer da anbringt aber er bringt det anEasterner says

$463 \mathrm{IN}$ : but he says it

$\underset{\operatorname{mhm} \downarrow}{\text { probably }^{*}}$

$464 \mathrm{BE}$ : wahrscheinlich äh äh ne jewisse mi"tschuld an diesen janzen in order to deny any responsibility for the forty years

$465 \mathrm{BE}: \quad$ vierzig jahrn für sich- ${ }^{\star}$ abzuweisen $\downarrow$ $466 \mathrm{IN}$ : $\mathrm{mhm} \downarrow^{\mathrm{ja} \uparrow} \operatorname{mhm} \operatorname{mhm} \downarrow^{* *}$

$467 \mathrm{BE}: \quad>$ kleener freispruch für ihn $\downarrow<{ }^{*}$ nach dem motto- ${ }^{*}{ }^{*}$ a little acquittal for him

The transcript segment begins with BE's negative prediction of the development of relations between East and West, and an explanation for it: the Ossis' hatred of Westerners (425-429). The interviewer's astonishment (wirklich "really", 430) and insisting question about the reasons for this statement provide the conditional relevance for BE to elaborate her perspective and to give reasons for it. She begins with a marker for perspective framing (des is mei" $n$ eindruck "this is my impression", 435 ), taking up the first part of the question which she confirmes ( $j a, 435)$ before the end of the interviewer's turn. The contrasting accent on mei" $n$ reinforces the opposition to the second part of the question (allgemeine eindruck "general impression"), and contextualizes the utterance as BE speaking from professional experience. Then she generalizes her prognostic abilities (437-441). Even though this self-praise is moderated by laughing, it imposes a strong obligation for evidence which is given in the following scene. In this scene, which took place right after the fall of the Berlin Wall, BE presents herself in a discourse with some Westerners about Easterners. The perspectivation of the scene - BE as advisor, the Westerners as willing recipients of advice - refers to BE's concept of her role as mediator for her Western clientele: she is the expert on the Eastern mind and its interpreter, and she is accepted in this role by her Western recipients. In this scene BE illustrates her knowledge about the deeply rooted divergence of perspectives between Ossis and Wessis.

The scene consists of two parts, starting with BE's self-quote, a reproach on the Westerners for their inadequate perspective of Easterners: also so" einfach geht det nich (442-444). The qualification so" einfach ("that simply") characterizes this view as naive in relation to the problem at hand. The reproach ih" $r$ könnt det schon ga"r nich- * mit dem äh o"stbürger so" machen wie i"hr euch det vorstellt ("you 
cannot treat others the way you want, especially not Easterners", 444-447), with a contrasting accent on $i h^{\prime \prime} r$ (in the sense of especially you cannot do that), implies that the Westerners are used to things being done their way, and that this is an extremely inadequate expectation in relation to the Easterners. With this, BE characterizes the Westerners as ignorant of the Easterners' minds and attitudes in relation to themselves.

BE's way of talking - she addresses her recipients in the second person "ihr" indicating a more personal relationship, and her direct and unmoderated reproach indicates that she sees herself in a position where she can speak explicitly and without moderation. She enacts the role of an expert with insider knowledge, and from that position she feels entitled to such reproach without running the risk of a rebuke or other kinds of negative sanctions; this can be concluded from the fact that she presents no reaction to her reproach. This implies that in BE's view, the Westerners are aware of their inadequate view of the problems at hand, and that they accept her censure and advice as an expert. The relationship between her and her Western interlocutors is characterized as informal, friendly and asymmetrical.

The second part of the scene deals with the Easterners' expectations and claims, and the Westerners' reaction to them. In relating the Eastern and Western perspectives to one another and showing their incompatibilty, BE constructs a kind of nonpartisan perspective from which she evaluates the justification of both groups' respective claims. She starts with the statement: weil die ham ooch ne vorstellung * bloß- ${ }^{*}$ die" stehn ja in einer erwartungshaltung- * die äh * die ihr überhaupt nich abdecken könnt ("they [the East citizens] have their ideas too and they have expectations which you can never satisfy", 447-453). From the Eastern perspective - as it is presented here - the relationship between Easterners and Westerners is asymmetrical: the Easterners see themselves in a position where they are justified making demands on the Westerners - demands that from BE's nonpartisan perspective exceed Western capacities (die ihr iiberhaupt nicht abdecken könnt). From the way she relates these two perspectives to each other, the specificity of her nonpartisanperspective can be inferred: the Eastern demands are presented in a quotation of Westerners in which these demands are rejected as completely irrational; the Eastern demands are presented through the Westerners' critical eyes, and BE sides with the Western evaluation of Eastern expectations.

This West-quotation starts with a drastic formula for rejection ihr müßt doch tullern ("you [Easterners] must be mad", 453-456); tullern is a Berliner expression for "verrückt sein"; with this harsh expression the Eastern demands ihr werft uns vor * wir mußten vierzig jahre lang krieg weiter spieln un nun könnt ih" $r$ zahln(456-460) are rejected. From the Eastern perspective, as it is displayed here, the relationship between East and West has a business quality, where the Easterners claim to have fulfilled their part of the deal, or rather were forced to fulfill it ("we 
had to go on playing war for forty years", 456-459). And now they demand that the Westerners accept the consequences: un nun könnt ihr zahln ("now you can pay", 459-460). The tasks connected with the war metaphor, "to make war" and "to pay for the costs of war" are distributed between the two parts of Germany, and they are positioned in a time-sequence. Having been forced to do their share, the Easterners feel themselves in a position where they can demand that the Westerners do their share too, implying that both parts were involved in this kind of "war" after 1945. The modal verb "müssen" ("have to") in mußten krieg spieln indicates that" being at war" was not the Easterners' own decision, but that "war" was imposed on them by outside political conditions. The Easterner is perspectivized as a victim of historical and political conditions and as not responsible for the forty years of history of the GDR. This interpretation of the East-West relationship reinforces the Eastern demands on the West for compensation. The Westerner is symbolized here as rude and dominant by his way of speaking (rude expressions, aggressive tone, no excuses or explanations); he rejects the other's perspective without giving reasons. This Western behavior implies that from the Western perspective the Eastern demands are so completely outside of normality that reasoning is unnecessary and rudeness an adequate expression of the Western contempt.

With this East-West dialogue a conflict situation is displayed where both partners ignore and exclude the other's perspective. The Easterner poses his demands grounded in his exclusive interpretation of German history after 1945; the Westerner demonstrates his unwillingness to take these demands seriously by rejecting them outright. Westerner and Easterner are generalized and typified: the presentation of the Westerner with his naivité, presupposing that things relating to reunification will naturally be done in the Western way, and with his unwillingness or incapability of taking the Eastern perspective into account, can be understood as an allusion to the stereotype of the "dominant Wessi" or the "Besserwessi" ("Western know-all"); the Easterner's absurd demands and assumptions that the Westerner will satisfy all his expectations seem to be an allusion to the stereotype of the "demanding Ossi".

The following comment on the Eastern demands contains an explicit valuation: is ja ooch total äh stussig ja wat de:r ostbürjer da anbringt aber er bringt det anum- ${ }^{*}$ wahrscheinlich äh äh ne jewisse mi"tschuld an diesen janzen vierzig jahrn für sich- * abzuweisen ia * kleener freispruch für ihn ("that is totally absurd what the Easterner says, but he says it * probably in order to deny any responsibility for the fourty years * a little acquittal for him", 460-467). The comment provides a possible motive for the Eastern perspective: the Easterner's desire to shift responsibility for the dictatorial GDR system to somebody else in order to be acquitted of any charges. "Kleener Freispruch" is a short-hand expression for the repression of guilt and the shifting of blame to another. 
The attribution of this motive for the Easterner's interpretation of the GDR history implies a change of perspective. The concept of responsibility and guilt in connection with the evaluation of the GDR's dictatorial system is a concept which "belongs" to the typical perspective of a GDR-exile towards the Ossi. From my ethnographic knowledge I know that the charge of being responsible for the injustice of the GDR system is a very common GDR-exile-reproach with the Easterner. In the GDR-exiles' perspective, most Easterners are to be blamed for supporting the GDR's dictatorial system, and for having betrayed everybody who opposed the system (i.e. the exiles themselves). In my experience, in discussions between Easterners and GDR-exiles, the question of blame and guilt and the Eastern tendency of shifting guilt to others is very central, and always leads to emotional outbreaks with heavy reproaches on the part of the exiles' and justifications on the part of the Easterners. ${ }^{15}$ On the basis of this background knowledge, I think that in presenting this special motive, $\mathrm{BE}$ changes from the nonpartisan perspective that she had constructed for herself to the GDR-exiles' perspective. She supports the Western evaluation of the Eastern demands ("they are totally absurd"), and she reveals that they are based on nothing but a petty and egotistic motive for evading the question of blame and guilt.

BE's perspectival work in the scene presented above and the comment on it can be taken as a cue to her concept of the role of mediator: in relation to the Westerners, she defines herself as an expert on the Eastern state of mind and as an expert on the Western reactions to Eastern demands. But in the evaluation of these demands as irrational she sides with the Western view. In her presentation of reasons for the Eastern demands she changes to the GDR-exiles' perspective, reveals the Eastern motives and condemns them morally.

\subsection{BE's near break-down of perspectivation}

Throughout the interview, BE produces very complex perspectival work, and she succeeds in separating the typified perspectives of the three antagonistic groups that she is talking about. The clear marking of the different perspectives has much to do with her clearly structured and consistent categorization practice. The three social categories are consistently presented in the following fashion: Ossis and Wessis with their strength and weakness, and with their respective prejudices and stereotypes. The category of "Übersiedler" is treated differently: it has no negative characteristics and its category-bound characteristics and activities are rather defined in relation to some of the negative characteristics of the category of "Ossi": 
Defining characteristics of "Ossi": Defining characteristics of "Übersiedler":

- irrational expectations about life - no expectations, realistic view of life ununder Western conditions der Western conditions

- complaints about the frustration - no complaints about the difficult condiof these expectations tions of life in the West

- opportunistic and cowardly un- - courageous under Eastern conditions, der Eastern conditions they stood up for their convictions

- dependent on others and helpless - independent of others' help and advice

When BE depicts the GDR-exiles' attitudes towards the other groups, she never mentions any negative emotions. In contrast to this, the Easterners' attitudes toward the other groups are presented as negative: They "hate" the Westerner (weil der Haß der Ostbürger gegen die Altbundesbürger so groß ist), they are filled with envy of the GDR-exiles, and they condemn them as landesverräter. In BE's presentation, the GDR-exiles' reactions to these expressions of deep aversion are always left out, made taboo.

Furthermore, BE evades the explicit presentation of herself as a GDR-exile; I inferred her membership in this category from her perspectival and categorizing practice. When, near the end of our interview, I asked her directly, she confirmed my assumption.

Only once, $\mathrm{BE}$ almost lost control of her categorizing work, and she got the perspectives mixed up. This becomes obvious in the following transcript segment. Following my question about the GDR-exiles' life in the West and their families, the following discourse sequence developed:

$819 \mathrm{BE}: \rightarrow$ ja die familien die sind ja meistens- ${ }^{*}$ ah die sind ja yes the families are mostlythey came with

$820 \mathrm{BE}$ : hierherjekomm mit kind und kejel oder so $\downarrow$ bag and baggage and the like

$821 \mathrm{IN}$ :

ach mit familie okay $\downarrow$ oh with familiy

$822 \mathrm{BE}:$ ja"ja- mit familie $\downarrow$ familie mein ik oma opa

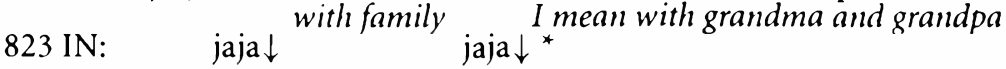

$824 \mathrm{BE}: \frac{\text { oder sonstwat }}{\text { or whatever }}$

$825 \mathrm{IN}$ : ja die kleinfamilie ${ }^{*}$ ich mein jetz also äh frau mann kinder yes the nuclear family I mean wife husband children 
826 BE: $\quad$ na die sin hier $\downarrow$

ja"ja $\downarrow \quad$ jaja $\downarrow$ they are here

827 IN: un so $\downarrow$ * die sinhier $\downarrow \quad$ ja $\downarrow \quad \mathrm{hm} \downarrow$ and so on they are here

$828 \mathrm{BE}: \quad \leftarrow$ und wenn die so also- ${ }^{* *}>\rightarrow$ die hatten ja/ nach der grenzand when theythey had/ after the fall

$829 \mathrm{BE}$ : öffnung durfte ja nun jeder/ denn diejenigen die ausjereist of the wall everyone was allowed/ because those who had left

$830 \mathrm{BE}: \quad$ sind hatt $=\mathrm{n}$ ja $*$ verbot jehabt $\leftarrow$

831 IN: had been prohibited

$<\mathrm{u}: \mathrm{nd}-* *$ and mhm jaja ich weiß $\downarrow$ yes I know

832 BE: >die:: äh äh muß:- ${ }^{*}$ die ham auch * $\leftarrow$ gro"ße verständijungsthcy äh äh had to- they have big communication

833 BE: schwierigkeiten $\downarrow$ * ja $\uparrow^{*} \rightarrow$ un fahrn ga"r nich gerne rüber $\downarrow$ * problems and they don't like to go over there

834 BE:

$$
\leftarrow \frac{<\text { weil da wieder }}{\text { because hatred }}
$$

835 IN: <mit denen die jetz drübn wohnen $\downarrow$ äh ham die kontakt/ ja with people living there now äh they do have contact/ yeah

836 BE: der hass hochkommt $\downarrow$

837 IN: will be welling up again $+<$ ah so $\downarrow$ * ah aha $\downarrow$ * $<$ der hass auf diel
äh- $\quad$ tauf oh yes oh well hatred against the/ against

838 BE: die:" $\downarrow$ ja:" $\downarrow$ * die eintlich mu"tig warn ja $\uparrow$ * zu 839 IN:

them auf die" $\uparrow$ yes who really were courageous who

840 BE: ner sache jesta"nden ham $\downarrow^{*}$ die wern je"tzt- * > von den äh stood up for their conviction they are now condemned by

$841 \mathrm{BE}$ : bürjern aus den fünf äh bundesländern- * a"bjeurteilt ja $\uparrow$ * the citizens of the five federal states

$842 \mathrm{BE}: \quad$ is nämlich ooch $=\mathrm{n}$ jewisser neid dahinter ja $\uparrow$ there is a certain envy behind it 
After the information that the GDR-exiles' families tend to live in the West, and the mutual agreement on that information which took considerable interactional effort to produce, BE delivers additional information (828-830). She appears to have formulation problems right from the beginning of this utterance; they are manifested by syntactic breaks, various restarts, a long pause, changes of grammatical subject (die, jeder, diejenigen) and changes in the prosodic contour. According to the rule of contiguity (Sacks 1987), the referential object of the first pronoun dic should be the previously mentioned noun familie (family of the GDR-exiles). Not until the final restart does it become manifest that there is a change of reference from the "family" to the "GDR-exiles" themselves. Relying on my backgroundknowledge, I can assume that this restart can be completed in this fashion: diejenigen die ausjereist sind hatt $=n$ [zu DDR-Zeiten] ja verbot jehabt [wieder einzureisen] (those who had left the GDR during the times of the GDR had been prohibited from reentering the country). ${ }^{16}$ The following sequence, again marked by manifest formulation problems surfacing in long filled and unfilled pauses, breaks and restarts, presents the GDR-exiles' contact experience with the Easterners: GDRexiles have communication problems with them. These problems became virulent only after the fall of the Wall; before that event, no contacts between Ossis and GDR-exiles were possible. The problems (gro"ße verständijungsschwierigkeiten "big communication problems", 832-833) as much as their solution (fahrn ga" $r$ nich gerne rüber "they don't like to go over there", 833) are treated as category-bound problems: They concern all GDR-exiles, and they solve them in the same fashion by avoiding contact. The formulation ga"r nich gerne implies that the motive for the contact avoidance is a negative emotion towards the Easterners. The litotes "ga" $r$ nicht gerne" in combination with the strong accent reveals the intensity of this feeling.

$\mathrm{BE}$ ignores the interviewer's remark in which she tries to come to terms with this information (835), and she presents the motive for the contact avoidance: wcil da wieder der haß hochkommt ("because hatred will be welling up again", 834-836). Since the inchoative formulation in the subordinate clause has neither referential subject nor object, co-reference between the "agent" of the main clause (= GDRexiles) and the persons to which "hatred" is attributed in the subordinate clause (= GDR-exiles) is structurally implied. The meaning of the utterance, as I inferred it, was that the GDR-exiles do not like to travel to the East and meet Ossis, because the old hatred (against Ossis) is welling up in them. Up until now, in BE's characterization of the three groups the characteristic of "hatred" was reserved for Easterners, and no negative attitudes were attributed to GDR-exiles. The new information that GDR-exiles hated Ossis came unexpectedly to me, and I wanted to make sure that I had understood it right: ah so * ah aha * der haß auf die/ "oh well ah aha the hatred against the/", 837). But before I could name the category, BE interrupted me, 
speaking louder and with conspicuous prosodic marking: <auf die:" $\downarrow$ ("against those", 836-838) which left me at a loss. Since she didn't fill in a category name, I asked again: auf die" $\uparrow$ ("against those", 839). Starting with the prosodically marked confirmation particle ja:" $\downarrow$ she continued with one of the category-bound characteristics of GDR-exiles die eintlich mu"tig warn ja $\uparrow^{*} z u$ ner sache jesta"nden ham ("who really were courageous and stood up for their conviction", 838-840). With this turn it becomes clear that it is not the GDR-exile who hates the Ossi - as it was projected by the clausal structure, and as I had inferred from BE's formulation but that the GDR-exile is hated by the Ossi.

Here BE changes perspectives within a single syntactic structure: The structurally projected "hater", the GDR-exile, becomes - by a sudden shift in perspective - the object of hatred. With this perspectival maneuver, namely a shift from the emotional state of the GDR-exile to the emotional state of the Easterner, BE manages to avoid the attribution of a strong negative feeling to the category of "Ubersiedler", and she succeeds in saving her official version of that category. That there exists an inofficial version too, a version, in which the "Ubbersiedler" has strong negative emotions against the Easterner, becomes obvious in her momentary confusion of perspectives. This confusion points to a contrasting unofficial version of the "Ubersiedler"'s attitudes which has remained hidden until now. The confusion of perspectives and the break in BE's perspectival work can be understood as an indicator that there exists a taboo, and the way in which her perspectivation breaks down indicates what kind of taboo it is.

Furthermore, with this perspectival maneuver $\mathrm{BE}$ avoids the topicalization of the hatred on the part of the "Ubersiedler", a topicalization which could be expected because of my previous reactions of misunderstanding. Being herself a member of the "Übersiedler"-category, BE protects herself from becoming a topic in the frame "hatred of members of the category "Übersiedler" against members of the category Ossi', where she could be obliged to disclose her own attitudes. In her former presentation she had avoided such a disclosure by avoiding all occasions that could lead to the topicalization of the GDR-exiles' feelings and attitudes towards Ossis.

\subsection{Some structural and contextual conditions for the perspectival break}

The question that now arises is: what leads $\mathrm{BE}$ to that almost-disclosure of the GDR-exiles' negative feelings or, in conversation analysis terms: what are the contextual and interactional reasons and conditions for the emergence of BE's confusion of perspectives? In order to answer this question we have to look at the interaction prior to BE's confusion of perspectives. 
Here BE delineates the "Übersiedler"'s category-bound characteristics and activities, and she closes her presentation with a specification: some "Übersiedler" have become "Einzelgänger" ("loners"):

$794 \mathrm{BE}: \quad$ für die war klar- * ${ }^{*}$ ich hab mich- * aus bestimmten gründen for them it was clear I have left this country for particular

$796 \mathrm{BE}$ : von dem staat äh abjeseilt- u:nd mir is bewu"Bt- ${ }^{*}$ daß

reasons

$h \mathrm{mh} \downarrow$ and I'm aware that I have

$798 \mathrm{BE}: \quad$ ich hier neu- * a"nfangn mu" $\ \downarrow$ 799 IN: to start from scratch over here

u:nd- * daß da eem keiner
and
that there isn't

$800 \mathrm{BE}:$ dastehn wird der dir- * äh- ** hilft oder so ja $\uparrow$ die anybody' to help me or whatever

$801 \mathrm{IN}$ : $m h \downarrow^{*}$

$802 \mathrm{BE}: \quad$ sin ulkijerweise auch- * äh mitunter- * ei"nzelgängertypen strangely cnough they occasionally became loners

$803 \mathrm{BE}: \quad$ jeworden $\downarrow$ *

$804 \mathrm{IN}$ : $\quad$ die früheren über ausreiseantrag $\downarrow$ * $\mathrm{mhm} \downarrow$ * people who came on an exit permit

805 IN: des heißt äh einzelgängertypen ham die jetzt keinc äh that means äh loners don't they have contact

806 IN: kontakte zu hiesigen oder auch keine kontakte mehr zu with people here, or don't they have any more contact

$807 \mathrm{BE}:$

$$
\text { " } \frac{\text { also sic/also- }}{\text { so they/so }}
$$

808 IN: ehemaligen- * DDRbürgern $\uparrow{ }^{*} \rightarrow \sin$ also(.....) to former citicens of the GD)R so they are (...)

809 BE: $\quad$ äh ** $\leftarrow$ sie lee"m für sich ei"nzel $\downarrow$ *

$810 \mathrm{IN}$ : they live alone

811 BE: nu"r ab un zu cemt- ${ }^{*}$ wie $=\mathrm{n}$ mannheim unserm verbandonly look from time to time like in Mannheim in our 
$813 \mathrm{BE}: \quad$ äh- ${ }^{*} \mathrm{ja} \downarrow{ }^{*} 2^{*} \#>$ ne begegnung- ${ }^{* *}$ für $=$ n geistigen aus/ yes organization for intellectual exchange

$814 \mathrm{~K} \quad$ \#FAINT, DEEP VOICE, HESITANTLY

$815 \mathrm{BE}:$ austausch- ${ }^{* *}$ ansonsten- ${ }^{* *}$ ham die kau"m- ${ }^{* *}$ freundotherwise they hardly ever have friendships

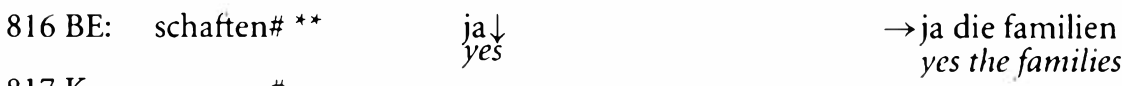

$817 \mathrm{~K}$

\#

$\mathrm{mhm} \downarrow * \quad \rightarrow$ auch keine familie $\uparrow * 2^{*}$ not even a familiy

$819 \mathrm{BE}:$ die sind ja meistens- * ah die sind ja hierherjekomm mit kind are mostlyah they came with bag and baggage

$820 \mathrm{BE}$ : und kejel

[for the following section see transcript above]

The attribution "Einzelgänger" ("loner", 802) does not have the quality of a category-bound characteristic: there is no apodictic generalization, the statement is modalized by ulkijerweise ("strangely", 802), and there is a validation of the statement which is restricted by mitunter ("occasionally", 802); the attribute "Einzelgänger" characterizes only some of the GDR-exiles. My reaction (804) shows how I processed this information, and I continue with a question regarding the GDRexiles' relation to people in the West and to people in the East: des heißt äh einzelgängertypen ham dic jetz keine äh kontakte zu hiesigen oder auch keine kontakte mehr $z$ u chemaligen- ${ }^{*}$ DDRbiirgern $\uparrow$ ("that means äh loners, don't they have contact with people here, or don't they have any more contact with former citizens of the GDR", 805-808). This outline of a two-sided relationship of the "loner" forms the structural frame for BE's following presentation: the loner's social contacts in the West and in the East. Thus, my question imposes a thematic relevance ${ }^{17}$ on $\mathrm{BE}$ and provides a structural frame for her presentation, that she must take into account. Before I can sum up my interpretation ( $\sin$ also, "that means they are", 808), $B E$ interrupts me, takes the turn, and describes the loner's social life in the West. This means that she accepts the thematic and structural imposition; she ratifies the established presentational schema, and starts with its first part.

For the first time in our interview BE reveals aspects of some GDR-exiles' inner life, and she presents some unexpected insights. Her presentation is most striking with regard to the choice of characteristics as well as her way of speaking:

- Choice of characteristics: some GDR-exiles live without friends, they have only strictly functional contacts with other GDR-exiles, and they are emotionaly isolated. 
- Manner of presentation: very slow tempo, hesitation marks, very deep and soft voice, long unfilled pauses after almost every word, implying that these emotional issues are painful and hard to talk about.

With these markers BE produces what could be called an 'interaction modality of confession ${ }^{18}$ which is ratified by the interviewer's signalling of empathy (back channels in deep voice, pauses after the speaker's turn, no further questioning). $\mathrm{BE}$ contextualizes the perspective of a person who is deeply involved in this kind of emotional experience. Although she speaks in the third person plural, all other formulation phenomena point to the fact that she presents a deeply felt inner state. Since this is her first reaction to my question it can be assumed - in line with Schütz' concept of 'interpretation relevance ${ }^{19}$ - that the described experience and the expressed feelings are at this point in our interview the most relevant to her. Here, she enacts the category of the "Übersiedler and loner" and she speaks from her own experience. The emergence of the interaction modality of confession is grounded in the thematic relevance imposed by my question, to which BE very readily turns, and in the interpretation relevance, that is: $\mathrm{BE}$ copes with the imposed topic in a fashion that spontaneously comes as the most "natural" to her in her present life situation: she lives in and suffers from this loneliness, and her first choice is to express these kinds of feelings very directly and without distance.

After the presentation of the GDR-exiles' social life in the West, the "logic" of the established structural schema as much as the established interaction modality form the interactional "forces" for the presentation of the second part of the schema, the GDR-exiles' social contacts in the East. This schema part follows my expansion about the GDR-exiles' families. BE starts with it on her own initiative (sec transcript above, 828), following the schematic imposition without my intervention. The "force" of this structural schema is the first condition for BE's topicalizing of the relationship between GDR-exiles and Ossis, which she has avoided so far. Topicalizing this relationship according to the previously established choice of characteristics implies that the emotional quality of the relation has to be treated as well - at least, it can hardly be left out. For this task, the formerly established interaction modality of confession forms the second interactional "force". The deeply felt inner state in depicting the loners' life in the West cannot suddenly be cut off in the next part of the schema. It "lingers" and also has effects on the following presentation. That means that the interaction modality of confession functions as the second force in the nearly emotional self-revelation, as $\mathrm{BE}$ works on the second part of the schema: she starts talking about the loners' inner life, their social problems and their feelings when they come into contact with the Ossis, in the same fashion she did in the previous part describing the loners' inner life in the West. 
I think that these two "forces", interactively established in the preceding sequences, are the conditions under which BE temporarily loses control of her deeply felt resentments towards the Easterners - emotions which severely interfere with her professional role as mediator and which, when disclosed and completely expressed, could cost her her job. These professional constraints seem to be the main reasons for $\mathrm{BE}$ to make her resentments taboo, resentments which are based on individual as well as on category-bound experiences.

\section{Summary}

One result of the rhetorical conversation analysis of a speaker's perspectival work is that his or her professional concept and self-positioning in relation to others can be reconstructed from this work. In our case, the speaker's professional role-concept in relation to three antagonistic groups that she has to deal with, as much as her view and evaluation of these groups and their respective perspectives to one another, can be derived. A precondition for this kind of reconstruction is the consistency of a speaker's perspectivation. This includes a consistency of the relationship between the social categories presented and the perspectives on objects or cases attributed to them.

A break in a speaker's perspectival work may indicate that there exist more aspects of a presented object or case than were revealed in the preceding discourse. Such a break can be brought about when - as in our case - the structural schema and interaction modality that have been negotiated by the participants impose an interactional logic on a speaker that forces him or her to reveal contradicting aspects of the presented case. From such a break 'secondary or inofficial versions' of the case may be inferred, versions which prior to the break had successfully been made a taboo. The fact that there is a break in a speaker's perspectivation indicates that there are hidden aspects to a presented case, and the structure of the break points to the quality of these aspects.

\section{Transcription conventions}

The transcription uses the signs of the German alphabet in analogy to the rules of pronunciation in German for the representation of the phonological and phonetic features of the spoken language, including dialectal spech. In addition, we use the following notation for prosodic features:

${ }^{*},{ }^{* *} \quad$ short pause, longer pause

$\uparrow, \downarrow,-\quad$ rising, falling and middle intonation 


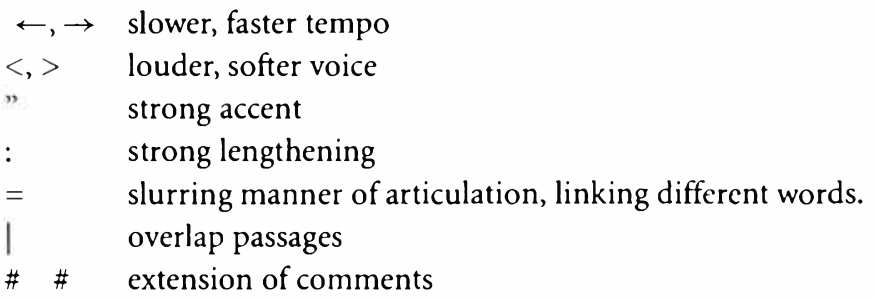

The English translation tries to keep close to the sequential structure of the German utterance if possible.

\section{Notes}

* I thank Jürgen Streeck for his help with the English version.

1. For the concept of a rhetorical conversation analysis, see Kallmeyer in this volume.

2. See Leibniz' "Monadologie" 1714, referred to in Graumann 1993: 157.

3. In literature, perspectivity has been an established analytical concept since the beginning of this century; generally known terms are "Erzählperspektive" (Stanzel 1979), "point of view" (Lubbock 1966), "Erzählerstandpunkt" (Weimann 1962). In spite of many subtle analyses of perspectivational techniques in fiction, according to Lindemann (1993) therc does not exist a satisfactory theory of verbal perspectivation.

4. Cf. especially the research on deixis by Fillmore (1972) and Ehlich (1979). As an independent concept of perspectivity the concept of "functional sentence perspectivity" was developed by the Prague linguistic school (see Danes \& Vieweger 1981). This perspectivity concept is based on the sentence structure and refers to the communicatively relevant information that the sentence contains.

5. This relation can be demonstrated by Fillmore's example: A prototypical commercial event involves the "seller", the "buyer", the "money" and the "goods". In a single clause, when talking about such a scene, a speaker has to choose one particular perspective on the scene. If he wishes to take the perspective of the seller and the goods, he chooses the verb "sell". With the choice of the verb a specific selection takes place, and some components are brought into perspective, while others stay in the background; with the choice of the verb "pay" the elements "buyer" and "money" are brought into perspective. With the verb and its perspectivizing potential only a specific part of the cognitve scene is perspectivated; cf. Fillmore (1977: 16ff.).

6. In the sentence construction "Hans schlägt Karl" "Hans" is understood as being in the foreground; but in the passive voice "Karl wird von Hans geschlagen", "Karl" is put into the foreground. For a good outline of different types of converses in relation to this perspectivity concept see Zifonun in this volume.

7. In her analysis of the German verb group "lügen", Storrer (1996) e.g. demonstrates the different semantic roles and the different perspectiation potentials of verbs such as "anlügen, vorlügen, belügen, sich durchlügen" etc. For questions of lexical derivational processes 
in combination with different actants and different perspectivational potentials see Helbig (1992, Chap. 3), Zifonun in this volume.

8. For an elaboration of this concept of perspectivation see Kallmeyer in this volume; I present only those parts of the concept, that are relevant for the analysis here.

9. These concepts consist of the following components: the perceiver's temporal, spatial, and cognitive standpoint; the perceived aspects of an object in relation to the standpoint; the keenness of the look at the object; and the objects' "inner" and "outer" horizon; see Graumann (1993).

10. The concept of contextualization was introduced into interaction analysis by Gumperz (1982a). In reaction to various comments on it, it was further elaborated and specified (1992), and is now a widely accepted concept for the analysis of the construction of social meaning in interaction.

11. The concept of social symbolization is based on Gumperz' concept of metaphorical code-switching (1982b), and is further elaborated and specified in Kallmeyer (1994), Kallmeyer and Keim (1994) and Kallmeyer (1995). It means the symbolic illustration of social and interactional characteristics of presented persons. These characteristics are expressed indirectly and implicitly, especially by kinesic, prosodic, phonological/phonetic, semantic and pragmatic means.

12. The concepts of relevance and social type are uscd according to Schütz, see Schütz and Luckmann (1975), Chap. III B “Relevanz", 186-228, and Chap. III C “Typik", 229-242. Schüt $z$ develops his concepts of relevance and typicality in relation to the construction of knowledge and its acquisition.

13. This statement is based on the conversational material I had the chance to document during some of the "Ossi-Übersiedler" meetings which were organized by the social orgaization "Bund der Mitteldeutschen"; in a vehement argument somc of the Ossis addressed the GDR-exiles with "ihr seid ja Vaterlandsverräter" (you are traitors of your home country), and in ethnographic interviews, the term "Vaterlandverräter" is often used when GDR-exiles describe how they are judged by Ossis.

14. In 1993 there was even a debate in the German parliament about an Eastern parliamentarian who had reproached a GDR-exile as a "Vaterlandsverräter".

15. BE herself was once deeply involved in such a discussion and broke down in tears. This discussion took place during a meeting between GDR-exiles and Ossis that she organized. I was a participant observer at this meeting. After my first ethnographic interview with $\mathrm{BE}$ she allowed me to take part in all group meetings she organized.

16. At least that is how I interpreted the utterance.

17. The term "thematic relevance" is used according to Schütz, cf. Schütz and Luckmann (1975: 190-197); see also Note 10 abovc.

18. 'Interaction modality' is a translation from the German term 'Interaktionsmodalität' which denotes a set of interpretive procedures by which a specific symbolic meaning is attributed to a representation, action or situation relating to special domains of meaning, such as "dream", "play", "seriousness", "joking" etc. This concept is based on A. Schütz' concept of the "finite provinces of meaning" (1962-1966, II: 230-259, 340ff.) and E. Goffman's concept 
of frame (1974). The concept takes into account the fact that a modal framing can cover interaction structures of various degrees of complexity. The change of interaction modality is marked by the speaker on various linguistic levels (prosody, lexico-semantics, syntax, pragmatics, kinesics) and is ratified or rejected by the recipient (laugh, corresponding utterance, back channels, refusal etc.)

19. Schütz distinguishes three types of relevance structure that are closely intervowen: (1) thematic relevance, referring to what object or event attracts or is made to attract the attention in a new situation; (2) interpretation relevance, referring to the way the object or event is related to the schematic knowledge and experience already acquired with regard to its typicality, and its congruences or incongruences with schemata and types already acquired; and (3) motivational relevance, referring to the way that the biographically acquired attitudes toward objects/events set typical reactions in motion and direct the attention when a new situation is being interpreted; cf. Schüt\% and Luckmann (1975, Kap. II B, "Relevanz").

\section{References}

Canisius, Peter, \& Marcus Gerlach (Eds.). (1993). Perspektivität in Sprache und Text (2nd enlarged edition). Bochum: Brockmeyer.

Danes, Frantisek, \& Dieter Viehweger (Eds.). (1981). Pragmatische Komponenten der Satzbedeutung. Berlin: Akademie der Wissenschaften der DDR.

Ehlich, Konrad (1979). Verwendungen der Deixis beim sprachlichen Handeln. Linguistischphilologische Untersuchungen zum Hebräischen. Forum Linguisticum, Bd. 24. Frankfurt: Lang.

Fillmore, Charles (1972). Ansätze zu ciner Theorie der Deixis. In F. Kiefer (Ed.), Semantik und generative Grammatik 1 (pp. 147-174). Frankfurt: Athenäum.

Fillmore, Charles (1977). The case for case reopened. In K. Heger \& J. Petöfi (Eds.), Kasustheorie, Klassifikation, semantische Interpretation (pp. 3-27). Hamburg: Helmut Buske.

(ioffman, Erving (1977). Rahmenanalyse. Frankfurt/M.: Suhrkamp.

Goffman, Erving (1975). Interaktionsrituale. Frankfurt/M.: Suhrkamp.

Graumann, Carl Friedrich (1989). Perspective setting and taking in verbal interaction. In R. Dietrich \& C. F. Graumann (Eds.), Language processing in social context (pp. 95-122). Amsterdam: North Holland.

Graumann, Carl Friedrich (1993). Perspektivität in Kognition und Sprache. SPIEL: Siegener Periodicum zur internationalen empirischen Literaturwissenschaft. Heft 2 (pp. 156-172). Berlin: Peter Lang.

Gumperz, John (1982a). Discourse strategies. Cambridge: Cambridge University Press.

Gumperz, John (1982b). Language and social identity. Cambridge: Cambridge University Press.

Gumpeř, John (1992). Contextualization revisited. In P. Auer \& A. di Luzio (Eds.), The contextualization of language (pp. 39-53). Amsterdam: John Benjamins.

Helbig, Gerhard (1992). Probleme der Valenz- und Kasustheorie. Tübingen: Niemeyer. 
Kallmeyer, Werner (1994). Das Projekt "Kommunikation in der Stadt". In W. Kallmeyer (Ed.), Kommunikation in der Stadt. Teil 1 (pp. 1-39). Berlin/New York: de Gruyter.

Kallmeyer, Werner (1995). Der kommunikative soziale Stil der "kleinen Leute" in der Filsbach. In Inken Keim, Kornmunikative soziale Stilistik einer sozialen Welt "kleiner Leute" in der Mannheimer Innenstadt (pp. 506-523). Berlin/New York: de Gruyter.

Kallmeyer, Werner (1996). Die Struktur von Perspektivität. In Werner Kallmeyer \& Inken Keim, Perspektivieren. Kap. 2.1.-2.4. MS.

Kallmeyer, Werner (Ed.) (in prep.). Rhetorik der Problem- und Konfliktbearbeitung. Schriften des Instituts für deutsche Sprache. Berlin: de Gruyter.

Kallmeyer, Werner \& Inken Keim (1994). Phonologische Variation als Mittel der Symbolisierung sozialer Identität in der Filsbachwelt. In Kallmeyer, Werner ( $\mathrm{Hg}$.) (pp. 141-249).

Kcim, Inken (1996): Verfahren der Perspektivenabschottung und ihre Auswirkung auf die Dynamik des Argumentierens. In W. Kallmeyer (Ed.), Gesprächsrhetorik. Zur Analyse von rhetorischen Verfahren in Gesprächsprozessen (pp. 191-277). Tübingen: Narr.

Keim, Inken (1996). Dominantsetzen von Perspektiven, Perspektivenabschottung und Überwinden von Perspektivenabschottung. In W. Kallmeyer (Ed.), Rhetorik der Problem- und Konfliktbearbeitung. Schriften des Instituts fur deutsche Sprache (in prep.), Chapter 6.1-6.3.

Lindemann, Bernhard (1993). Einige Fragen an eine Theorie der sprachlichen Perspektivierung. In Canisius \& Gerlach (Hg.) (pp. 1-39).

Lubbock, Percy (1966). The craft of fiction. London: Cape.

Sacks, Harvey (1987). On the preference for agreement and contiguity in sequences in conversation. In G. Button \& J. R. E. Lee (Eds. ), Talk and social organization (pp. 54-69). Clevedon: Multilingual Matters.

Sandig, Barbara (1996). Sprachliche Perspektivierung und perspektivierende Stile. LILI, Sprache und Subjektivität II, 26, Hft. 102, 36-63.

Schütz, Alfred (1961-1966). Collected papers, Vol. I-III. The Hague: Nijhoff.

Schütz, Alfred, \& Thomas Luckmann (1975). Strukturen der Lebensivelt. Darmstadt: Luchterhand.

Stanzel, Franz (1979). Theorie de's Erzählens. Göttingen: Vandenhoeck \& Ruprecht.

Storrer, Angelika (1996). Verbbedcutung und Situationsperspektivierung. In J. Grabowski, G. Harras, \& Th. Herrmann(Eds.), Bedeutung Konzepte Bedeutungskonzepte (pp. 231255). Opladen: Westdeutscher Verlag.

Weimann, Robert (1962). Erzählerstandpunkt und point of view. Zeitschrift fïr Anglistik und Amerikanistik, 10, 369-416.

Zifonun, Gisela (1997). Grammatik der Ereignisperspektivierung. In G. Zifonun, L. Hoffmann, \& B. Strecker (Eds.), Grammatik der deutschen Sprache. Schriften des Instituts für deutsche Sprache (Chapter F4). Berlin/New York: de Gruyter. 